The Bangladesh Veterinarian (2016) 33(1): 8 - 15

\title{
Avian influenza and Newcastle disease virusindead chickens in markets in Dhaka, Bangladesh in 2011-2012
}

\author{
LR Barman1, RD Sarker, BC Das¹, EH Chowdhury, PM Dasand MR Islam* \\ Department of Pathology, Faculty of Veterinary Science, Bangladesh Agricultural \\ University, Mymensingh-2202, Bangladesh
}

\begin{abstract}
A virological survey for avian influenza (AI) and Newcastle disease (ND) was conducted in two selected live bird markets (LBMs), namely Kaptan Bazar and Karwan Bazar in Dhaka city, Bangladesh from August 2011 to July 2012. A total of 513 dead chickens were collected. An immune-chromatographic rapid antigen test for Type A influenza virus and both conventional and real time RT-PCR were used for the detection and characterization of $\mathrm{AI}$ and ND viruses. All carcasses were first screened by the rapid antigen test kit and 93 were positive for Type A influenza virus. RT-PCR on a representative number of rapid antigen test positive samples $(n=24)$ confirmed the presence of Type A influenza virus and mostly H5 influenza virus (22 out of 24 tested samples). Influenza rapid test negative samples $(n=420)$ were subjected to routine necropsy. Heat stress, suffocation and physical injury were the most common cause of mortality (163 cases), followed by ND, suspected to be the cause of 85 deaths. On molecular investigation of these 85 samples, the presence of ND virus was confirmed in 59 and AI virus in 6; 15 were negative for both ND and AI viruses and 5 were unsuitable for investigation. Among the $59 \mathrm{ND}$ confirmed cases 18 also contained AI virus. In summary, out of 513 carcasses 117 (22.81\%) contained AI virus and $59(11.50 \%)$ contained ND virus. Eighteen $(3.51 \%)$ carcasses contained both AI and ND viruses. The findings suggest that both $\mathrm{AI}$ and ND should be considered as major threats to the poultry industry. (Bangl. vet. 2016. Vol. 33, No. 1, 8 - 15)
\end{abstract}

\section{Introduction}

Outbreaks of diseases are major constraints in poultry farming in Bangladesh. Avian influenza (AI) and Newcastle disease (ND) cause severe damage to the poultry industry. Highly pathogenic avian influenza (HPAI) H5N1 was first reported in Bangladesh in 2007 (Islam et al., 2008; Biswas et al., 2008) and the disease became well established. The introduction of clade 2.2 H5N1 HPAI virus in Bangladesh was followed by introduction of clade 2.3.2.1 and clade 2.3.4 in 2011 (Islam et al., 2012). In 2011 and 2012 poultry farms of Bangladesh experienced HPAI outbreaks at an unprecedented scale.

Newcastle disease, also called Ranikhet disease, is a highly contagious viral disease distributed worldwide. VelogenicviscerotropicND is endemic in Bangladesh (Talha et al., 2001; Barman et al., 2010; Rashid et al., 2013) and has caused serious economic loss.

\footnotetext{
${ }^{1}$ Department of Livestock Services, Dhaka, Bangladesh

*Corresponding author:- email: mrislam_bau@yahoo.com
} 
In developing countries live bird markets (LBMs) spread viruses like avian influenza virus (AIV) and Newcastle disease virus (NDV) (Fourniéet al., 2013; Zhu et al., 2014). Major LBMs in Dhaka serve as the hub for poultry from all over Bangladesh. In the present study a virological surveillance in dead birds in selected LBMs in Dhaka was undertaken to evaluate the extent of circulation of NDV and AIV.

\section{Materials and Methods}

Preliminary demographic survey at LBMs

A cross-sectional demographic survey on five big LBMs in Dhaka city was conducted to gather information on the number and types of live birds brought for sale per day and the number of birds found dead in the markets.

\section{Collection and examination of carcasses}

Based on the findings of preliminary cross-sectional demographic survey, two of the biggest wholesale LBMs of Dhaka (Kaptan Bazar and Karwan Bazar) were selected. On average, 10-12 freshly dead chickens were collected from each market every 15 days for one year from August 2011 to July 2012. A total of 513 carcasses were collected.

All carcasses were first screened for Type A AIV using an immuno-chromatographic rapid antigen test kit (Flu detect ${ }^{\circledR}$, Synbiotics, USA) on tracheal swabs following manufacturer's instructions. Tracheal swabs were collected from 24 out of 93 positive carcasses for confirmation of the presence of virus by RT-PCR. All the Type AAIVnegativecarcasses $(n=420)$ were subjected to routine necropsy. The gross lesions were recorded and a tentative diagnosis was made. From ND suspected birds $(n=85)$, pooled tissues from lungs, trachea, spleen, caecal tonsils and proventriculus were collected aseptically in Falcon tubes for further investigation.

\section{$R T-P C R$ and real time RT-PCR}

All the collected tissue samples were homogenized in sterile PBS and tested for the detection and molecular characterization of AIV and NDV by conventional RT-PCR and real-time RT-PCR (rRT-PCR). RNA was extracted from tissue homogenate on a robotic RNA extraction machine, King Fisher ML (Thermo Fisher, USA), using AmbionMagMAX Viral RNA Isolation Kit (Life Technologies, USA).A conventional RT-PCR (Fouchieret al., 2000) and anrRT-PCR (Spackman et al., 2002) were used for Type A influenza virus $M$ gene fragment. Then a subtype-specific conventional RTPCR was done for H5 gene fragment (Lee et al., 2001). For the detection of NDV a conventional RT-PCR for F gene fragments (Wang et al., 2006) and anrRT-PCR for M gene fragment (Wise et al., 2004; Khan et al., 2010) were used. SupeScript III One Step RT-PCR kit with Taq DNA polymerase (Life Technologies, USA) was used in conventional RT-PCR and AmbionAgPath-ID One Step RT-PCR Kit (Life Technologies, USA) was used in rRT-PCR following manufacturer's instructions. 


\section{Results and Discussion}

The preliminary demographic survey revealed that on average, 621,900 live birds were brought to five big markets in Dhaka every day (Table 1). Kaptan Bazar appeared to be the biggest, followed by Karwan Bazar. About $52 \%$ of the marketed birds were local non-descript free-range chickens and cross-bred Sonali chickens (Fayoumix RIR), 42\% were broilers and spent hens, 5\% were ducks and other water fowls and $1 \%$ were pigeons and other birds. The proportion of different types of birds varied between the markets. On average $0.10 \%$ (range $0.09 \%-0.14 \%$ ) of the total marketed birds were found dead daily.

A total of 513 dead chickens were sampled from Karwan Bazar and Kaptan Bazar. On rapid antigen test $93(18.13 \%)$ were positive for Type A influenza virus. The remaining 420 carcasses, which were negative, were subjected to detailed necropsy: the results are in Table 2 . The most common cause $(31.77 \%)$ of mortality was heat stress, suffocation and physical injury. Apart from avian influenza the next highest probable cause of mortality was Newcastle disease, which was suspected in $16.56 \%$ $(85 / 513)$ carcasses. Other important diseases or conditions associated with mortality included Gumboro disease, coccidiosis, acute pneumonia and chronic respiratory disease, egg bound peritonitis, misshapen and haemorrhagic ovarian follicles, and enteritis.

Table 1. Number and types of live birds brought for sale per day in five biggest markets of Dhaka city and the number of birds found dead in the markets

\begin{tabular}{|c|c|c|c|c|c|c|}
\hline \multirow[t]{2}{*}{ Markets } & \multicolumn{5}{|c|}{ Average number* of birds marketed per day } & \multirow{2}{*}{$\begin{array}{c}\text { Average } \\
\text { number }(\%) \\
\text { of dead birds } \\
\text { per day }\end{array}$} \\
\hline & $\begin{array}{c}\text { Chickens } \\
\text { (Local non- } \\
\text { descript, and } \\
\text { Sonali) }\end{array}$ & $\begin{array}{l}\text { Chickens } \\
\text { (Broiler and } \\
\text { commercial } \\
\text { spent hens) }\end{array}$ & $\begin{array}{c}\text { Ducks \& } \\
\text { other } \\
\text { water- } \\
\text { fowl }\end{array}$ & $\begin{array}{l}\text { Pigeon, } \\
\text { quail, etc. }\end{array}$ & Total & \\
\hline Kaptan Bazar & 255,300 & 203,500 & 21,200 & 5,100 & 485,100 & $450(0.09 \%)$ \\
\hline Karwan Bazar & 30,100 & 36,100 & 4,400 & 1,900 & 72,500 & $85(0.12 \%)$ \\
\hline Mirpur 1 & 13,200 & 9,300 & 800 & 500 & 23,800 & $22(0.09 \%)$ \\
\hline $\begin{array}{l}\text { Mohammadpur Krishi } \\
\text { Market }\end{array}$ & 15,900 & 5,600 & 1,100 & 400 & 23,000 & $23(0.10 \%)$ \\
\hline Mohakhali Kacha Bazar & 6,200 & 8,800 & 1,900 & 600 & 17,500 & $25(0.14 \%)$ \\
\hline Total & $\begin{array}{c}320,700 \\
(51.57 \%)\end{array}$ & $\begin{array}{c}263,300 \\
(42.34 \%)\end{array}$ & $\begin{array}{c}29,400 \\
(4.73)\end{array}$ & $\begin{array}{c}8,500 \\
(1.37 \%)\end{array}$ & $\begin{array}{l}621,900 \\
(100 \%)\end{array}$ & $\begin{array}{c}605 \\
(0.10 \%)\end{array}$ \\
\hline
\end{tabular}

*Average of three independent observations from June to August, 2011. Figures are rounded up tohundreds

The results of RT-PCR and rRT-PCR for AIV and NDV are in Fig. 1 and Fig. 2. All the 24 AI rapid test positive samples were positive in RT-PCR for Type A avian influenza virus M gene. Of these, 22 were positive for H5 HA gene and 2 were negative. All 24 samples were negative for NDV on both conventional and real time RT-PCR. 
Table 2. Diseases or conditions tentatively diagnosed by AIV rapid antigen test and necropsy among dead chickens collected from live bird markets

\begin{tabular}{|c|c|c|c|c|}
\hline \multirow[t]{2}{*}{ Diseases or conditions diagnosed } & \multicolumn{3}{|c|}{ Number of cases } & \multirow{2}{*}{$\begin{array}{l}\text { Percentage among } \\
\text { total dead birds } \\
\quad(\mathrm{n}=513)\end{array}$} \\
\hline & $\begin{array}{c}\text { Local non-descript } \\
\& \text { Sonali chickens } \\
\text { and commercial } \\
\text { spent hens }\end{array}$ & Broilers & Total & \\
\hline \multicolumn{5}{|c|}{ Diagnosis based on Rapid Antigen Test for Avian Influenza (No. examined = 513) } \\
\hline Avian influenza & 93 & 0 & 93 & $18.21 \%$ \\
\hline \multicolumn{5}{|c|}{ Diagnosis based on necropsy (No. examined $=420$, AI rapid test negative carcasses) } \\
\hline Newcastle disease & 84 & 1 & 85 & $16.56 \%$ \\
\hline Coccidiosis & 25 & 2 & 27 & $5.26 \%$ \\
\hline Gumboro disease & 1 & 13 & 14 & $2.72 \%$ \\
\hline Gumboro disease and Coccidiosis & 2 & 6 & 8 & $1.55 \%$ \\
\hline Acute pneumonia & 7 & 6 & 13 & $2.53 \%$ \\
\hline Chronic respiratory disease & 10 & 0 & 10 & $1.94 \%$ \\
\hline Egg bound peritonitis & 23 & 0 & 23 & $4.48 \%$ \\
\hline $\begin{array}{l}\text { Misshapen \& hemorrhagic egg } \\
\text { follicles }\end{array}$ & 15 & 0 & 15 & $2.92 \%$ \\
\hline Enteritis & 20 & 1 & 21 & $4.09 \%$ \\
\hline Fowl cholera & 1 & 0 & 1 & $0.19 \%$ \\
\hline Necrotic enteritis & 1 & 0 & 1 & $0.19 \%$ \\
\hline Gangrenous dermatitis & 1 & 0 & 1 & $0.19 \%$ \\
\hline Ascariasis & 1 & 0 & 1 & $0.19 \%$ \\
\hline Visceral tumors & 10 & 0 & 10 & $1.94 \%$ \\
\hline Fatty liver & 7 & 0 & 7 & $1.36 \%$ \\
\hline Malnutrition & 9 & 0 & 9 & $1.75 \%$ \\
\hline $\begin{array}{l}\text { Heat stress, suffocation or } \\
\text { physical injury }\end{array}$ & 160 & 3 & 163 & $31.77 \%$ \\
\hline Undiagnosed conditions & 18 & 0 & 18 & $3.50 \%$ \\
\hline Decomposed carcass & 8 & 0 & 8 & $1.55 \%$ \\
\hline Total & 481 & 32 & 513 & $100.00 \%$ \\
\hline
\end{tabular}

Pooled tissue samples of 80 out of 85 ND suspected carcasses were tested for NDV by RT-PCR (five were not suitable for the test as the tissues were autolysed). Out of 80 samples 59 were positive for NDV on RT-PCR. Among the remaining $21 \mathrm{NDV}$ negative samples 6 were positive for AIV on rRT-PCR, of which one was $\mathrm{H} 5$ positive. Among the 59 NDV-positive samples, 18 were also positive for AIV on rRT-PCR, of which 9 were H5-positive. 
The results reconfirmed that the rapid antigen test is highly specific, as all the AI rapid antigen test-positive samples were positive by RT-PCR. However, many samples $(n=24)$ that were negative in AI rapid antigen test were positive for AIV in RT-PCR, indicating the limited sensitivity of rapid test. On the other hand, as many as 21 carcasses suspected at necropsy to have died of ND were negative for NDV in RTPCR, six of which were actually AIV positive. So, one should not rely only on necropsy for the diagnosis of ND. Concurrent infection with NDV and AIV is also possible. The co-circulation of NDV and AIV might be overlooked when diagnostic approach concentrates on one virus only.

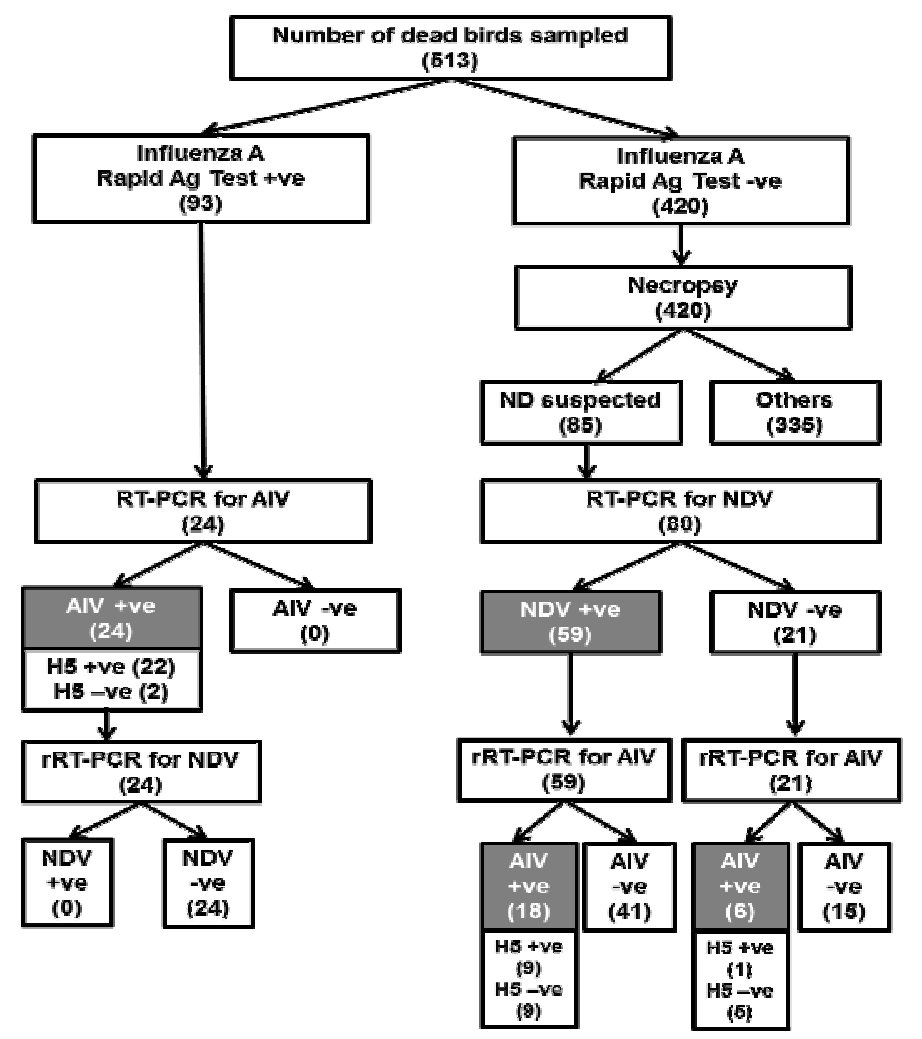

Fig. 1. Summary of rapid antigen test, necropsy, RT-PCR and rRT-PCR results of dead bird samples from two LBMs of Dhaka city

Live bird markets in Bangladesh are the hub for poultry traders, where birds from different species and locations are brought together. Live bird markets are of prime concern with regard to disease transmission as birds from commercial farms as well as backyard farms are brought together and housed in small areas, allowing easy contamination of cages, food and water. LBM in Asia and Africa often act as reservoirs for different genotypes of virulent and avirulent NDV (Byarugaba et al., 2014; Zhu et al., 2014; Kouakou et al., 2015; Zhang et al., 2015) and can circulate potential pathogens. The results of the present study support these observations. 


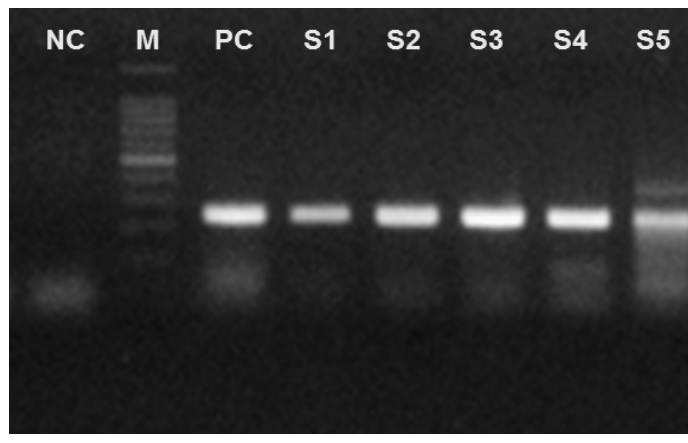

Fig. 2a. Amplification of Type A influenza virus M gene (245 bp) fragment by RT-PCR

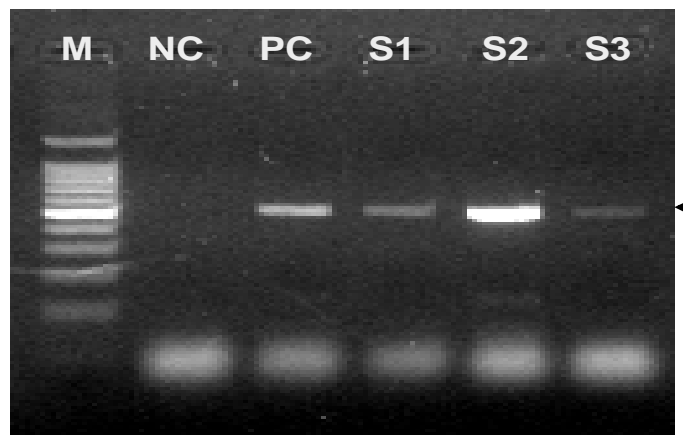

Fig. 2c. Amplification of $\mathrm{F}$ gene fragment (535 bp) of Newcastle disease virus by RTPCR

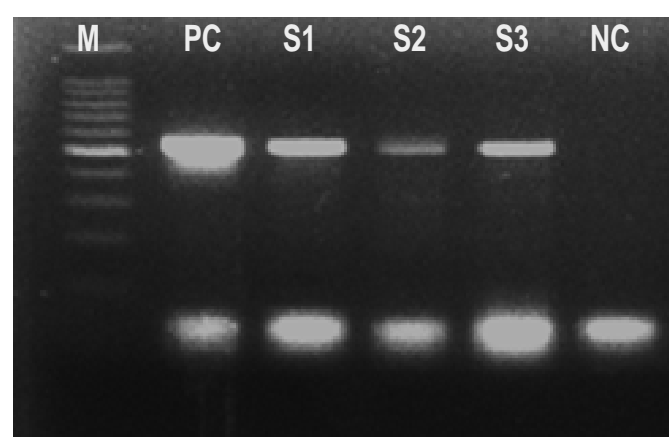

Fig. 2b. Amplification ofH5 gene fragment (545 $\mathrm{bp}$ ) of avian influenza virus by RT-PCR

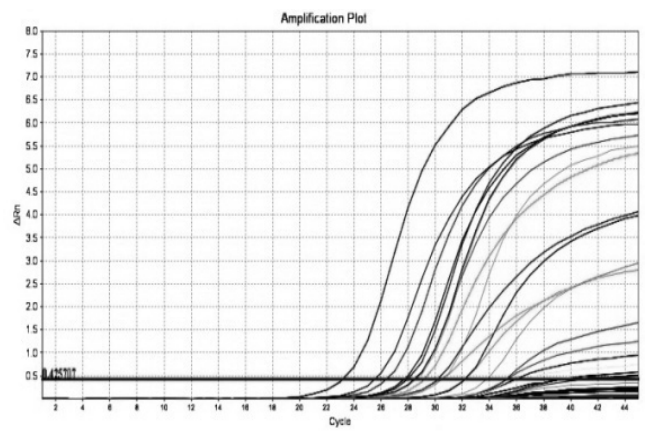

Fig. 2d. Amplification plot of real time RT-PCR for $\mathrm{M}$ gene of avian influenza virus

In conclusion, a substantial number of birds (about $0.10 \%$ ) were found dead every day in two big wholesale LBMs. In 2011 - 2012both NDV and AIV were widely circulating in LBMs. Concurrent infection with both AIV and NDV was detected in some dead birds.

\section{References}

Barman LR, Flensburg MF, PerminA, Madsen M, Islam MR 2010: A controlled study to assess the effects of vaccination against Newcastle disease in village chickens. The Bangladesh Veterinarian 27 56-61.

Biswas PK, Christensen J, Ahmed SSU, Barua H, Das A, Rahman MH, Giasuddin M, Hannan ASMA, Habib MA, Ahad A, Rahman ASMS, Faruque R, Debnath NC 2008: Avian influenza outbreaks in chickens, Bangladesh. Emerging Infectious Diseases 14 1909-1912

Fouchier RA, Bestebroer TM, Herfst S, Kemp VD, Rimmelzwaan LGF, Osterhaus AD 2000: Detection of influenza A viruses from different species by PCR amplification of conserved sequences in the matrix gene. Journal of Clinical Microbiology 38 4096-4101. 
Byarugaba DK, Mugimba KK, Omony JB, Okitwi M, Wanyana A, Otim MO, Kirunda H, NakavumaJL, Teillaud A, Paul MC, Ducatez MF 2014: High pathogenicity and low genetic evolution of avian paramyxovirus type I (Newcastle disease virus) isolated from live bird markets in Uganda. Virology Journal 11173.

Fournié G, Guitian J, Desvaux S, Cuong VC, Dung DH, Pfeiffer DU, Mangtani P, Ghani AC 2013: Interventions for avian influenza A (H5N1) risk management in live bird market networks. Proceedings of the National Academy of Sciences of the USA 110 9177-9182.

Islam MR, Baqi MA, Giasuddin M, Samad MA 2008: Molecular characterization and phylogenetic analysis of highly pathogenic H5N1 avian influenza virus of chickens of Bangladesh. Proceedings of the Bangkok International Conference onAvian Influenza 2008: Integration from Knowledge to Control. 23-25 January, Bangkok, Thailand.

Islam MR, Haque ME, Giasuddin M, Chowdhury EH, Samad MA, Parvin R, Nooruzzaman M, Rahman MM, Monoura P2012: New introduction of clade 2.3.2.1 avian influenza virus (H5N1) into Bangladesh.Transboundary Emerging Diseases 59 460-463.

Khan TA, Rue CA, Rehmani SF, Ahmed A, Wasilenko JA, Miller PJ, Afonso CL 2010: Phylogenetic and biological characterization of Newcastle disease virus isolates from Pakistan. Journal of Clinical Microbiology 48 1892-1894.

Kouakou AV, Kouakou V, Kouakou C, Godji P, Kouassi AL, Krou HA, Langeois Q, Webby RJ, Ducatez MF, Couacy- Hymann E 2015: Prevalence of Newcastle disease virus and infectious bronchitis virus in avian influenza negative birds from live bird markets and backyard and commercial farms in Ivory-Coast. Research inVeterinary Science 102 83-88.

Lee MS, Chang PC, Shien JH, Cheng MC, Shieh HK 2001: Identification and subtyping of avian influenza viruses by reverse transcription-PCR. Journal of Virological Methods $\mathbf{9 7}$ 13-22.

Rashid MH, Xue C, Islam MR, Islam MT, Cao Y 2013: A longitudinal study on the incidence of mortality of infectious diseases of commercial layer birds in Bangladesh. Preventive Veterinary Medicine 109 354-358.

Spackman E, Senne DA, Myers TJ, Bulaga LL, Garber LP, Perdue MI, Lohman K, Daum K, Suarez DL 2002: Development of a real-time reverse transcriptase PCR assay for type A influenza virus and the avian H5 and H7 hemagglutinin subtypes. Journal of Clinical Microbiology 40 3256-3260.

Talha AFSM, Hossain MM, Chowdhury EH, Bari ASM, Islam MR, Das PM 2001: Poultry diseases occurring in Mymensingh district of Bangladesh. The Bangladesh Veterinarian 18 20-23.

Wang Z, Liu H, Xu J, Bao J, Zheng D, Sun C, Wei R, Song C, Chen J 2006: Genotyping of Newcastle disease viruses isolated from 2002 to 2004 in China. Annals of the New York Academy of Sciences 1081 228-239. 
Wise MG, Suarez DL, Seal BS, Pedersen JC, Senne DA, King DJ, Kapczynski DR, Spackman E 2004: Development of a real-time reverse-transcription PCR for detection of Newcastle disease virus RNA in clinical samples. Journal of Clinical Microbiology $\mathbf{4 2}$ 329-338.

Zhang P, Xie G, Liu X, Ai L, Chen Y, Meng X, Bi Y, Chen J, Sun Y, Stoeger T, Ding Z, Yin R 2015: High genetic diversity of Newcastle disease virus in wild and domestic birds in Northeastern China from 2013 to 2015 reveals potential epidemic trends. Applied and Environmental Microbiology 82 1530-1536.

Zhu J, Xu H, Liu J, Zhao Z, Hu S, Wang X, Liu X 2014: Surveillance of avirulent Newcastle disease viruses at live bird markets in Eastern China during 2008-2012 reveals a new sub-genotype of class I virus. Virology Journal 11211. 